\title{
DETECTION OF VIRULENCE ASSOCIATED GENES IN LISTERIA MONOCYTOGENES ISOLATED FROM DISEASED FARM ANIMALS
}

\author{
"Ahmed Ali El Sawaak, ${ }^{* *}$ Ibrahim El Sayed El Desoky, ${ }^{* * *}$ Ahmed Mohamed Abd \\ Elgwaad, \\ ${ }^{* * * *}$ Hanaa A. Ahmed and ${ }^{* * *}$ Marwa Ibrahim El Morsy Shalaby. \\ "Pathology Dept. Fac. of Vet. Med. Kafrelsheikh Univ., Egypt. \\ ** Bacteriology, Mycology and Immunology Dept. Fac. of Vet. Med. \\ Kafrelsheikh Univ., Egypt. \\ ${ }^{* * *}$ Animal health research institute, Mansoura Provincial Laboratory. \\ ${ }^{* * * *}$ Head of Genome Research Unite, AHRI.
}

\begin{abstract}
A total of 631 different samples (milk, faeces, brain and Cerebrospinal fluid) were collected from 268 diseased farm animals and emergency slaughtered animals (80 sheep, 60goat, 75 cattle and 53 buffaloes) from Dakahlia Governorate in 2014 and 2015. The samples were tested for presence of L. monocytogenes by isolation and biochemical identification.

The results revealed that L. monocytogenes was presented in diseased and emergency slaughtered sheep, goat, cattle and buffaloes in ratio of (36.5\%),(28.67\%),(24.48\%), (17.4\%) respectively. Using multiplex PCR technique, detected the presence of virulence-associated genes
\end{abstract}


(inlA, inlC, inlJ, inlB, plcB, hylA, jap and plcA).

\section{INTRODUCTION}

L. monocytogenes is a food borne pathogen of major concern with regard to public and animal health. This bacterium affects a wide range of mammalian species, most commonly humans and domestic ruminants (Chen et al., 2007). L. monocytogenes isolates were small, Grampositive rods, negative for oxidase and urease, and test-positive for methyl red and Voges-Proskauer, had the ability to grow at $35^{\circ} \mathrm{C}$, were catalase-positive and motile in wet mounts. They utilized dextrose, esculin and utilized rhaminose with production of acid but failed to utilize xylose Osman et al., (2014). Clinical manifestations are similar in all susceptible hosts and include septicemia, abortion, severe gastroenteritis, and central nervous system (CNS) infections, such as meningitis, meningoencephalitis, and rhombencephalitis Zhang et al., (2003). Identification of infected animals was necessary due to the likely causal link to several outbreaks of listeriosis. Rawool et al., (2007).

Four key of L. monocytogenes virulence genes (i.e plcA, hly, $a c t A$, and $p l c B$ ) that are critical for the intracellular life cycle Ward et al., (2004). The hemolysin (listeriolysin O), two distinct phospholipases, a protein (ActA), several internalins, and others had been identified and extensively characterized at the molecular and cell biologic levels Kathariou $S$ (2002).

This study was done to throw spot light on molecular characterization of $L$. monocytogenes infection in some farm animals including sheep, goat, cattle and buffaloes in El-Dakahlia governerate. 
The namely inlA, inlC, inlJ.plcA, act A, hlyA and jap, inlB and plcB genes for L. monocytogenes were chosen as target genes throughout this study.

\section{MATERIAL AND METHODS}

A total of 631samples were collected from268 diseased farm animals and emergency slaughtered animals (80 sheep, 60 goat, 75 cattle and 53 buffalo). Such samples including faeces (80), cerebrospinal fluid (17), milk (32) and brain (60) from diseased sheep, faeces (60), cerebrospinal fluid (11), milk (17) and brain(48)] from diseased goat, faeces (75), milk (62) and brain (46) from diseased cattle and faeces (53), milk (41) and brain(29) from diseased buffaloes.

These samples were collected from different village of Dakahlia Governorate. Samples were collected separately in sterile plastic bag, well identified and transported in ice box $\left(4^{\circ} \mathrm{C}\right)$ under strict hygienic condition to Mansoura Veterinary laboratory within $2 \mathrm{hrs}$.

\section{Isolation of L. Monocytogenes:}

The technique recommended by United Stated Department of Agriculture (USDA), Food Safety and Inspection Service "FSIS" (1989) and $\boldsymbol{F A O}$ (1992) was adapted.

Twenty five gm. from each brain- faeces sample were aseptically weighted and homogenized in primary selective Listeria Enrichment Broth, University of Vermont Medium provided from Biolife $($ LEBUVM $)$ and incubated at $30^{\circ} \mathrm{C}$ for 24 hours then $0.1 \mathrm{ml}$ of incubated $\left(\mathrm{LEBUVM}_{1}\right)$ will be transferred to $10 \mathrm{ml}\left(\mathrm{LEBUVM}_{\mathrm{II}}\right)$ and incubated at 33- $37^{\circ} \mathrm{C}$ after 24 hours of incubation a loopful from enrichment culture $\mathrm{UVM}_{\text {II }}$ broth were streaked onto PALCAM agar plates (oxoid CM,877) 
containing selective supplement (oxoid SR150), then incubated at $35-37^{\circ} \mathrm{C}$ for 24-48 hours (Jemmi and Keusch, 1994).

Milk samples and C.S.F.: (FDA, Lovett et.al., 1987): twenty five ml. of milk were added to $225 \mathrm{ml}$. of Enrichment Broth Modified tryptone soya broth containing $0.6 \%$ yeast extract, Nalidixic cid $40 \mathrm{mg} / 1$, Acriflavine hydrochloride $15 \mathrm{mg} / 1$ and incubated at $30^{\circ} \mathrm{C}$ for $48 \mathrm{~h}$ then $0.1 \mathrm{ml}$ of enrichment broth was streaked on PALCAM agar plates (oxoid CM,877) containing selective supplement (oxoid SR150), then incubated at $30^{\circ} \mathrm{C}$ for 48 hours.

\section{Identification of L. Monocytogenes (ISO, 11290):}

The suspected colonies (drop-like, black with brown hallow with sunken center) were picked up and subcultured on Trypticase Soya agar supplemented with $0.6 \%$-yeast extract (TSA-YE) and incubated at $30^{\circ} \mathrm{C}$ for 24then identified according to $\boldsymbol{F A O}$ (1992), Bacterial films from the suspected pure colonies were stained with Gram's stain and using appropriate biochemical tests (Catalase test, $\mathrm{H}_{2} \mathrm{~S}$ production, D-glucose, salacin fermentation (Purple Agar Base, Oxidase test, and Vogas proskouer reaction and umbrella type motility at $22^{\circ} \mathrm{C}$. Further identification to species were done using heamolysis on blood agar, Nitrate reduction, acid production from D-xylose, L-raminose, D-Mannitol and methyl- d- mannoside.

\section{Detection of associated virulence genes of $10 \mathrm{~L}$. monocytogenes isolates by multiplex PCR for :}

Bacterial strans :A collection of 10 L.monocytogenes were investigated. The collection contained (5,2, 1 and 2) straines from brain, C.S.F., faeces and milk respectivelly from ruminant with listeric encephalitis. 
Template DNA extraction according to (Liu et. al., 2007).

AmpliTaq Gold® 360 Master Mix (U.S.A., Applied Bio System Code No.439881) and Oligonucleotides primer

Table (1): Oligonucleotides primer sequences and expected product sizes of the multiplex PCR:

\begin{tabular}{|c|c|c|c|c|}
\hline Gene & & Primer sequence $\left(5^{\prime} \rightarrow 3^{\prime}\right)$ & $\begin{array}{c}\text { Expected } \\
\text { product size }\end{array}$ & Reference \\
\hline \multirow{2}{*}{ inlA } & Forward & ACGAGTAACGGGACAAATGC & \multirow{2}{*}{$800 \mathrm{bp}$} & \multirow{6}{*}{ Liu et. al., 2007} \\
\hline & Reverse & CCCGACAGTGGTGCTAGATT & & \\
\hline \multirow{2}{*}{ inlC } & Forward & AATTCCCACAGGACACAACC & \multirow{2}{*}{$517 \mathrm{bp}$} & \\
\hline & Reverse & CGGGAATGCAATTTTTCACTA & & \\
\hline \multirow{2}{*}{ inlJ } & Forward & TGTAACCCCGCTTACACAGTT & \multirow{2}{*}{$238 \mathrm{bp}$} & \\
\hline & Reverse & AGCGGCTTGGCAGTCTAATA & & \\
\hline \multirow{2}{*}{ inlB } & Forward & AAAGCACGATTTCATGGGAG & \multirow{2}{*}{$146 \mathrm{bp}$} & \multirow{4}{*}{$\begin{array}{c}\text { Sanghun } \\
\text { et. al., } 2012\end{array}$} \\
\hline & Reverse & ACATAGCCTTGTTTGGTCGG & & \\
\hline \multirow{2}{*}{$p l c B$} & Forward & GGGAAATTTGACACAGCGTT & \multirow{2}{*}{$261 b p$} & \\
\hline & Reverse & ATTTTCGGGTAGTCCGCTTT & & \\
\hline \multirow{2}{*}{ plc A } & Forward & $\begin{array}{l}\text { CTGCTTGAGCGTTCATGTCTCATCCCCC } \\
\end{array}$ & \multirow{2}{*}{$1484 \mathrm{bp}$} & \multirow{8}{*}{$\begin{array}{c}\text { S. Kaur } \\
\text { et. al., } 2007\end{array}$} \\
\hline & Reverse & CATGGGTTTCACTCTCCTTCTAC & & \\
\hline \multirow{2}{*}{ hly A } & Forward & GCAGTTGCAAGCGCTTGGAGTGAA & \multirow{2}{*}{$456 \mathrm{bp}$} & \\
\hline & Reverse & GCAACGTATCCTCCAGAGTGATCG & & \\
\hline \multirow{2}{*}{ jap } & Forward & ACAAGCTGCACCTGTTGCAG & \multirow{2}{*}{$131 \mathrm{bp}$} & \\
\hline & Reverse & TGACAGCGTGTGTAGTAGCA & & \\
\hline \multirow{2}{*}{$\operatorname{act} A$} & Forward & CGCCGCGGAAATTAAAAAAAGA & \multirow{2}{*}{$839 \mathrm{bp}$} & \\
\hline & Reverse & ACGAAGGAACCGGGCTGCTAG & & \\
\hline
\end{tabular}

The mixture used and the reaction conditions for Multiplex PCR for the detection of inlA, inlC and inlJ were according to Liu et. al., (2007).

The mixture used and the reaction conditions for Multiplex PCR for the detection of inlB, $p l c B$ were according to Sanghun et. al., (2012). 
The mixture used and the reaction conditions for Multiplex PCR for the detection of plcA, hylA, jap and actA were according to S. Kaur et. al., (2007)

Agarose gel electrophoresis was done according to Sambrook et al., (1989).

\section{RESULTS}

Total incidence of Listeria monocytogenes in diseased farm animals samples by culture isolation method:

It is evident from the table (2) that the prevalence of L. monocytogenes in diseased sheep was (36.5) the higher rate of isolation was from C.S.F (47.05\%) followed by brain (43.3\%), milk $(32.5 \%)$ and from feaces $(28.1 \%)$. The prevalence of L. monocytogenes in diseased goat was (28.67) isolated from (23.3\%), (29.4\%), (31.25\%) and $(36.36 \%)$ from feaces, milk, brain, and C.S.F respectively, while in diseased cattle the prevalence of L. monocytogenes was (24.48) from faeces (28\%), milk (20.9\%) and brain (24.48\%). As shown in table (2) that the prevalence of $L$. monocytogenes in diseased buffaloes isolated in a ratio of $(26.4 \%),(12.1)$, and (10.3\%) from faeces, milk and brain respectively.

Table (2): Total incidence of L. monocytogenes in diseased farm animals samples by culture isolation method:

\begin{tabular}{|c|c|c|c|c|c|c|c|c|c|c|c|c|c|c|c|c|}
\hline \multirow{3}{*}{ Animals } & \multirow{3}{*}{$\begin{array}{l}\text { No. of } \\
\text { animals }\end{array}$} & \multicolumn{5}{|c|}{ Type and number of samples } & \multicolumn{10}{|c|}{ Positive } \\
\hline & & \multirow{2}{*}{ Faeces } & \multirow{2}{*}{ Milk } & \multirow{2}{*}{ Brain } & \multirow{2}{*}{ C.S.F } & \multirow{2}{*}{ Total } & \multicolumn{2}{|c|}{ Faeces } & \multicolumn{2}{|c|}{ Milk } & \multicolumn{2}{|c|}{ Brain } & \multicolumn{2}{|c|}{ C.S.F. } & \multicolumn{2}{|c|}{ Total } \\
\hline & & & & & & & No. & $\%$ & No. & $\%$ & No & $\%$ & No & $\%$ & No & $\%$ \\
\hline
\end{tabular}




\begin{tabular}{|c|c|c|c|c|c|c|c|c|c|c|c|c|c|c|c|c|}
\hline Sheep & 80 & 80 & 32 & 60 & 17 & 189 & 26 & 32.5 & 9 & 28.1 & 26 & 43.3 & 8 & 47.05 & 69 & 36.5 \\
\hline Goat & 60 & 60 & 17 & 48 & 11 & 136 & 14 & 23.3 & 5 & 29.4 & 15 & 31.25 & 4 & 36.36 & 39 & 28.67 \\
\hline Cattle & 75 & 75 & 62 & 46 & 0 & 183 & 21 & 28 & 13 & 20.9 & 13 & 24.48 & 0 & 0 & 48 & 24.48 \\
\hline Buffaloe & 53 & 53 & 41 & 29 & 0 & 123 & 14 & 26.4 & 5 & 12.1 & 3 & 10.3 & 0 & 0 & 24 & 17.4 \\
\hline Total & 268 & 268 & 152 & 183 & 28 & 631 & 75 & 27.98 & 37 & 20.55 & 47 & 25.68 & 12 & 42.85 & 180 & 27.31 \\
\hline
\end{tabular}

Multiplex Polymerase chain reaction (PCR) for detection of associated virulence genes of $L$. monocytogenes:

The multiplex PCR allowed amplification of 9 virulence-associated genes of $L$. monocytogenes, namely plcA, act $\mathrm{A}, h l y \mathrm{~A}$ and jap, inlB, plcB, inlA, inlC and inlJ. to their respective base pairs, 1484, 839, 456, 131, 146, 261, 800, 517 and 238 bp PCR products, respectively, each represented by a single band in the corresponding region of the DNA marker ladder, all of the amplification products were of the expected size, except for the $a c t A$ gene did not produced by ay examined strain in this study.

Table (3): Detection of virulence associated genes in $10 \mathrm{~L}$. monocytogenes isolates by multiplex PCR:

\begin{tabular}{|c|c|c|c|c|c|c|c|c|c|c|c|}
\hline \multirow{2}{*}{$\begin{array}{l}\text { No. of the } \\
\text { isolates }\end{array}$} & \multicolumn{9}{|c|}{ Virulance associated genes } & \multirow{2}{*}{$\begin{array}{l}\text { Animal } \\
\text { species }\end{array}$} & \multirow{2}{*}{$\begin{array}{l}\text { Origin of } \\
\text { the sample }\end{array}$} \\
\hline & inlA & inlC & inlJ & inlB & ,plcB & $p l c \mathrm{~A}$ & $\operatorname{act} \mathrm{A}$ & hlyA & iap & & \\
\hline 1 & - & - & - & - & - & - & - & - & - & Sheep & Feaces \\
\hline 2 & - & - & - & - & - & - & - & + & + & cattle & Milk \\
\hline 3 & + & + & + & - & + & - & - & + & + & Sheep & C.S.F \\
\hline 4 & - & + & + & - & + & - & - & + & + & cattle & Brain \\
\hline 5 & - & + & + & - & - & - & - & + & + & Sheep & Milk \\
\hline 6 & + & + & + & + & + & + & - & + & + & Sheep & Brain \\
\hline 7 & + & + & + & + & + & + & - & + & + & Sheep & C.S.F \\
\hline 8 & + & + & + & + & + & + & - & + & + & goat & Brain \\
\hline 9 & + & + & + & - & + & + & - & + & + & cattle & Brain \\
\hline
\end{tabular}




\begin{tabular}{||c||c||c||c||c||c||c||c||c||c||c||c||}
\hline \hline 10 & + & + & - & - & + & + & - & + & + & buffloe & Brain \\
\hline
\end{tabular}

Detection of virulence associated genes (inlA $(50 \mathrm{pmol})$, inlC $(30 \mathrm{pmol})$ and inlJ (25pmol)) in 10 L. monocytogenes isolates by multiplex PCR:

Photo (1) showed that L. monocytogenes isolates produced (60\%), (80\%) and (80\%) of InlA, InlC and inlJ gene respectively.

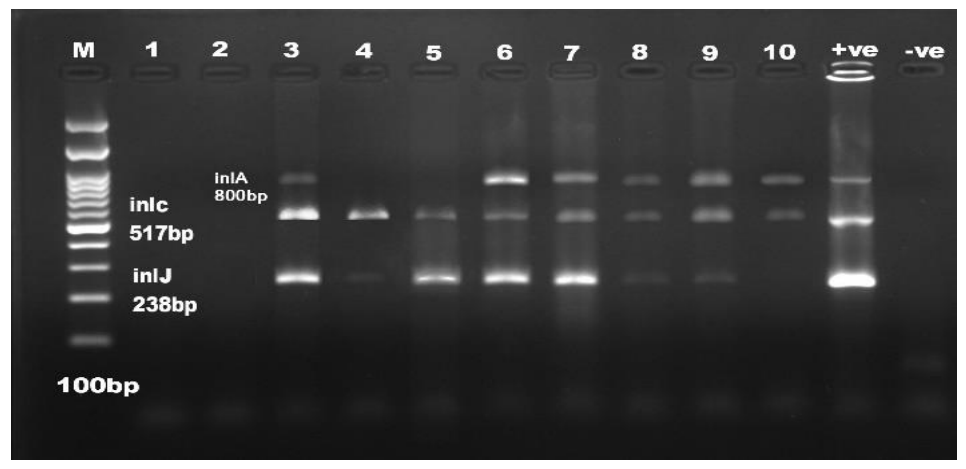

Photo (1): Ethidium bromide stained 2\% agarose gel electrophoresis showing the standard PCR of the 1-10: suspected L. monocytogenes DNA from the examined samples +ve: positive control of $L$. monocytogenes, ve: negative.

Detection of virulence associated genes (plcB and inlB) in $10 \mathrm{~L}$. monocytogenes isolates by multiplex PCR:

The results in Photo (2) show that (70\%) of L. monocytogenes isolates produced plcB gene and (30\%) of L. monocytogenes isolates produced inlB gene. 


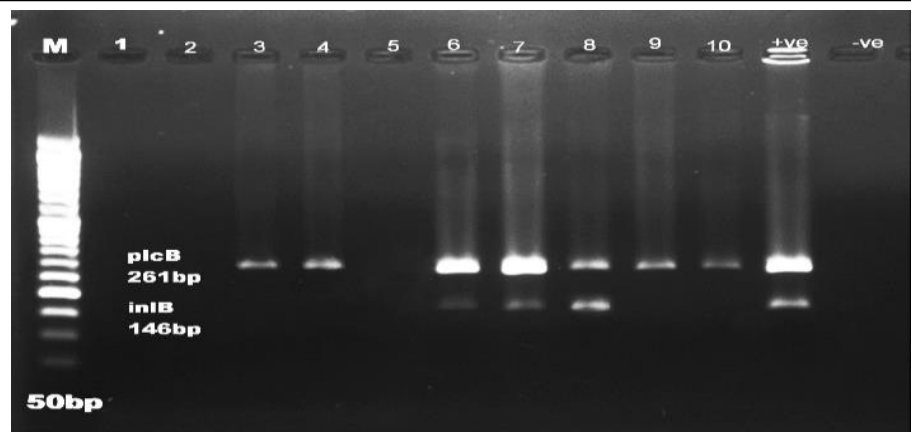

Photo (2): Ethidium bromide stained 2\% agarose gel electrophoresis showing the standard PCR of the 1-10: suspected L. monocytogenes DNA from the examined samples +ve: positive control of $L$. monocytogenes and -ve: negative.

Detection of virulence associated genes (jap, hylA, act $\mathrm{A}$ and $p l c \mathrm{~A}$ ) 50pmol in 10 L. monocytogenes isolates by multiplex PCR:

It is evident from photo (3) that (90\%) of L. monocytogenes isolates produced hylA gene, (80\%) of L. monocytogenes isolates produced jap gene and (50\%) of L. monocytogenes isolates produced plcA gene

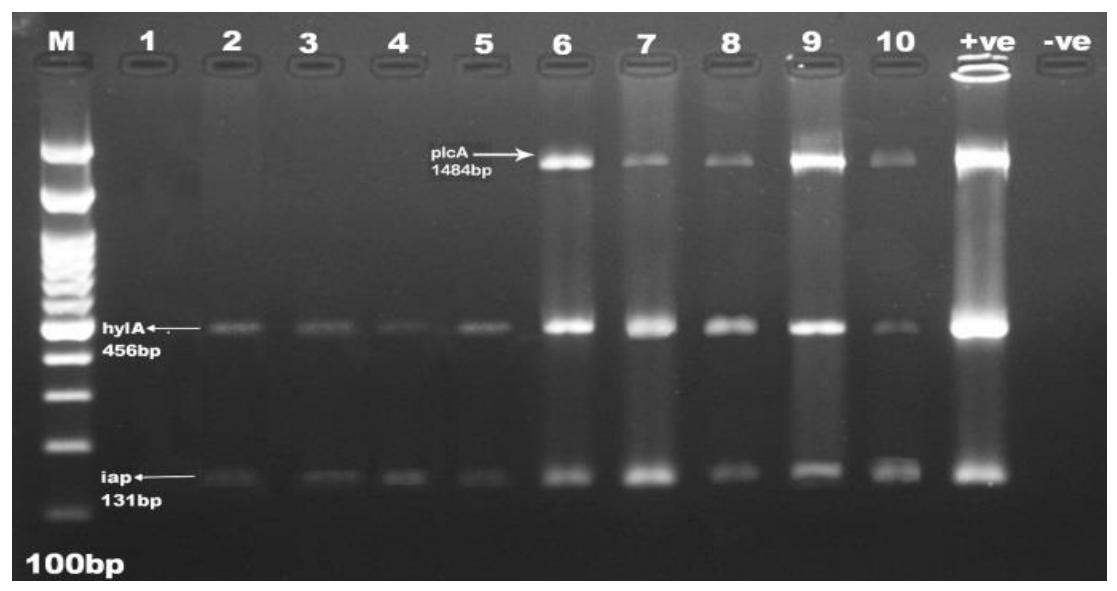

Photo (3): Ethidium bromide stained 2\% agarose gel electrophoresis showing the standard PCR of the 1-10: suspected L. monocytogenes DNA Kafrelsheikh Vet. Med. J. Vol. 14 No. 1 (2016) 
from the examined samples +ve: positive control of $L$. monocytogenes and -ve: negative.

\section{DISCUSSION}

Enrichment of L. monocytogenes was done on the UVMI and UVM $\mathrm{UI}_{\mathrm{II}}$ broth (Jemmi and Keusch 1994). Isolation of L. monocytogenes were done on the PALCAM media with selective supplement, typical colonies recovered were grey-green 1.5- 5 in diameter, and have black sunken centers due to esculin hydrolysis as the results obtained by (Parihar et. al., 2008).

Results in table (2) for the bacteriological examination on 268 diseased farm animals and emergency slaughtered animals (80 sheep, 60 goat, 75 cattle and 53 buffalo) revealed that $(36.5 \%, 28.6 \%, 24.48 \%$ and $17.4 \%$ ) isolated from sheep, goat, cattle and buffaloes respectively were nearly similar to the results that recorded by (Simranpreet et. al., (2010); Antônio et. al., 2014; Osman et al., 2014). Higher figures were reported by Esteban et. al., (2009). Meanwhile lower prevalence was recorded by F. A. Lawan et. al., (2013).

The variation in the isolation rate may be due to variation in methods of isolation Jemmi and Keusch, (1994) and variation in animal husbandry practice and type of animal species $\boldsymbol{F}$. A. Lawan et. al., (2013).

Results in Table (2) showed that L. monocytogenes was recovered from the C.S.F., brain, faeces and milk of the examined sheep was (47.05\%), (43.3\%), (32.5\%), and (28.1\%) respectively. These results agree with (Elgamal A. M. 2003; Antônio et. al., 2014). 
The results achieved of the isolation of L. monocytogenes from fecal samples of sheep agree with $\boldsymbol{F}$. A. Lawan et al., (2013). Lower rate of isolation were recognized by Esteban et. al., (2009).

The isolation of L. monocytogenes from sheep milk samples agree with Osman et al., (2014). Lower rate of prevalence recorded by Ebrahim et. al., (2014).

Table (2) declares that that L. monocytogenes was recovered (36.36\%), (31.25\%), (23.3\%) and (29.4\%) from the C.S.F., brain, feaces and milk of the examined goats.

The isolation rates of L. monocytogenes from C.S.F. and brain samples of diseased goat were in the ranges which agree with Antônio et. al., (2014). Lower rate of isolation were recognized by Shivasharanappa et. al., (2014).

The result of isolation of $L$. monocytogenes from milk of diseased goat samples agrees with Osman et. al., (2014). The lower rate recognized by Ebrahim et. al., (2014).

The isolation of L. monocytogenes from faeces of diseased goat samples were in the range which agrees with $F$. A. Lawan et. al., (2013); Farad et. al., (2013)

L. monocytogenes were recovered from the brain, faeces and milk of the examined cattle in a ratio of $(24.48 \%),(28 \%)$ and $(20.9 \%)$ respectively as shown in Table (2); which agree with Antônio et. al., (2014). 
The isolation of L. monocytogenes from fecal samples of diseased cattle agrees with $\boldsymbol{F}$. A. Lawan et. al., (2013).

Isolation of L. monocytogenes from milk samples of diseased cattle agrees with Alejandra et. al., (2009); while higher rate of isolation of $L$. monocytogenes recorded by Deepansh et. al., (2012).

Table (2) approved that L. monocytogenes recovery rate from the brain, feaces and milk of the examined buffaloes were (10.3\%), (26.4\%), (12.1\%) respectively, these results agree with Simranpreet et.al., (2010). Lower rate of isolation was recorded by Chaudharia et. al., (2004).

The isolation of L. monocytogenes from milk samples of diseased buffloes agrees with Deepansh et. al., (2012); Farad et. al., (2013).

Multiplex PCR assay was carried out for detection of $L$. monocytogenes and presence of inLA, inLC, inlJ, inlB, plcB, plcA, hlyA, actA and jap genes.

However, some L. monocytogenes strain may lack one or more virulence determinants because of some mutation Cooray et. al., (1994).

As shown in photo (1) L. monocytogenes isolates produced (60\%), (80\%) and (80\%) of InlA, InlC and inlJ gene respectively. The combined application of inLA which is species-specific, inLC and in $L J$ gene primers in a multiplex PCR confirm L. monocytogenes species identity and its potential virulence Jaradat et. al., (2002).

The results in photo (2) show that (70\%) of L. monocytogenes isolates produced $\mathrm{plcB}$ gene and $(30 \%)$ of L. monocytogenes isolates

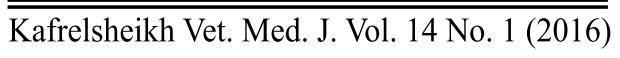


produced $i n l B$ gene. $I n l B$ is not an important virulence factor for listeriosis Liu et. al., (2007) recognized that InlB gene failed to be recognized with serotype 4 strains.

The result in photo (3) that $(90 \%)$ of $L$. monocytogenes isolates produced hylA gene, (80\%) of L. monocytogenes isolates produced jap gene and (50\%) of L. monocytogenes isolates produced plcA gene.

Roche et. al., (2009) stated that some isolates of L. monocytogenes harbor inlA gene with or without hlyA gene which supported the usefulness of studying the pathogenic potential of strains.

\section{REFERENCES}

- Alejandra A. Latorre; Jo Ann S. Van Kessel2; Jeffrey S. Karns; Michael J. Zurakowski;Abani K. Pradhan; Ruth N. Zadoks;Kathryn J. Boor;Ynte H. Schukken.(2009): Molecular Ecology of Listeria monocytogenes: Evidence for a Reservoir in Milking Equipment on a Dairy Farm. Applied Environmental Microbiology March 2009 vol. 75 no. 5 1315-1323.

- Antônio Carlos Lopes Câmara; André Menezes do Vale'; Jael Soares Batista; Francisco Marlon C. Feijó; Benito Soto-Blanco (2014): Suppurative intracranial processes in 15 domestic ruminants. Pesq. Vet. Bras. vol.34 no.5 Rio de Janeiro May 2014.

- Chaudhari, S.P.; Malik, S.V.S.; Chatlod, L.R. and Barbuddhe, S.B. (2004): Isolation of pathogenic Listeria monocytogenes and detection of antibodies against phosphatidylinositol-specific phospholipase $\mathrm{C}$ in 
buffaloes Comparative Immunology, Microbiology and Infectious Diseases Volume 27, Issue 2, March 2004, Pages 141-148.

- Chen, Y., W. Zhang, and S. J. Knabel. (2007): Multi-virulence-locus sequence typing identifies single nucleotide polymorphisms which differentiate epidemic clones and outbreak strains of Listeria monocytogenes. J. Clin. Microbiol. 45835-846)

- Cooray, K. J., Nishibori, T., Xiong, H., Matsuyama, T., Fujita, M. and Mitsuyama, M. (1994): Detection of multiple virulenceassociated genes of Listeria monocytogenes by PCR in artificially contaminated milk samples. Appl. Environ. Microbiol. 60:3023-3026.

- Deepansh Sharma; Pradeep Kumar Sharma; B. S. Saharan2 and Anjali Malik (2012): International Journal of Microbial Resource Technology, Vol.1, No.1 (Jan 2012), 1-4 1.

- Ebrahim Rahimi, Hassan Momtaz, Asma Behzadnia and Zeinab Torki Baghbadorani (2014): Incidence of Listeria species in bovine, ovine, caprine, camel and water buffalo milk using cultural method and the PCR assay Asian Pac J Trop Dis. 2014 Feb; 4(1): 50-53.

- Elgamal A.M. (2003): Bacteriological Investigation of Listeriosis Epizootic in Sheep Flock in El-Dakhlia province. Zag. Vet. J. (ISSN. 1110-1458) Vol 31, No., (2003) PP. 85-90.

- Esteban, J.I.; Oporto, B.; Aduriz, G.; Juste,R.A.; and Hurtado, A.; (2009): Faecal shedding and strain diversity of Listeria 
monocytogenes in healthy ruminants and swine in Northern Spain BMC Veterinary Research 2009, 5:2 .

- FAO (1992): Manual of food quality control. 4 Rev. Chapter 11, pp. 119-129. 1. Microbiological analysis of food and Agriculture Organization of the United Nations, Rome.

- Farad Safarpoor Dehkordi; Sara Barati; Hassan Momtaz; Seyyedeh Nasib Hosseini Ahari; and Shahin Nejat Dehkordi(2013): Comparison of Shedding, and Antibiotic Resistance Properties of Listeria monocytogenes Isolated From Milk, Feces, Urine, and Vaginal Secretion of Bovine, Ovine, Caprine, Buffalo, and Camel Species in Iran. Journal of Microbiology. 2013 May; 6(3): 284-94.

- FSIS "United State Department of Agriculture, Food Safety Inspection Service (1989): Method for the isolation and identification of Listeria monocytogenes from meat and poultry products. Laboratory Communities. No. 57, US Department of Agriculture, Washington, D.C.

- F. A. Lawan; A. N. Tïjani; A. I. Raufu; J. A. Ameh; I. Y. Ngoshe and M. S. Auwal (2013): Isolation and characterisation of Listeria species from ruminants in Maiduguri north-eastern Nigeria. African Journal of Biotechnology, Vol. 12(50), pp. 6997-7001.

- Jaradat ZW; Schutze GE ;Bhunia AK (2002): Genetic homogeneity among Listeria monocytogenesstrains from infected patients and meat products from two geographic locations determined by phenotyping, 
ribotyping and PCR analysis of virulence genes.Int J Food Microbiol. 2002 Jun 5;76(1-2):1-10.

- Jemmi, T. and Keusch, A. (1994): Occurrence of Listeria monocytogenes during processing and storage of experimentally contaminated hot smoked trout, Int. J. Food Microbial., 15: 339-346.

- Kathariou S. (2002): L.monocytogenes virulence and pathogenicity, a food safety perspective. J Food Prot. 2002 Nov; 65 (11):1811-29.

- Liu, D.; Lawrence, M.L.; Austin, F.W.; Ainsworth, A.J. (2007): A multiplex PCR for species- and virulence-specific determination of Listeria monocytogenes. Journal of Microbiological Methods 71: 133-140.

- Osman KM; Zolnikov TR; Samir A; Orabi A (2014): Prevalence, pathogenic capability, virulence genes, biofilm formation, and antibiotic resistance of Listeria in goat and sheep milk confirms need of hygienic milking conditions.Pathog Glob Health. 2014 Jan; 108 (1):21-9.

- Parihar VS, Barbuddhe SB, Danielsson-Tham ML, Tham W. (2008): Isolation and characterization of Listeria species from tropical seafood. Food Control 19566-569.569.

- Rawool, D. B., S. V. Malik, I. Shakuntala, A. M. Sahare, and S. B. Barbuddhe. (2007): Detection of multiple virulence-associated genes in Listeria monocytogenes isolated from bovine mastitis cases. Int. J. Food Microbiol. 113:201-207. 
- Roche, S.; Kerouanton, A.; Minet, J.; Le Monnier, A.; Brisabois, A. and Velge, P. (2009): Prevalence of low virulence Listeria monocytogenes strains from different foods and environments. Int. J. Food Microbiol., 130(2): 151 -155.

- Sambrook, J.; Fritsch, E.F. and Maniatis, T. (1989): Molecular cloning: a laboratory manual. Cold Spring Harbor Laboratory Press, New York.

- Sanghun Park; Jihun Jung; Sungsun Choi;Younghee Oh; Jibho Lee; Heesun Chae; SeungheeRyu;Hyowon Jung; Gunyong Park; Sungmin Choi; Bogsoon Kim; Junghun Kim; Young Zoo Chae; Byungyeol Jung; Myunghun Lee; Hyunsoo Kim (2012): Molecular Characterization of Listeria monocytogenes Based on the PFGE and RAPD in Korea. Advances in Microbiology Vol. 2 No. 4 (2012), Article ID: 26214, 12 pages.

- Shivasharanappa Nayakwadi; Vivek Kumar Gupta; Rajveer Singh Pawaiya; Gundallahallai Bayyappa Manjunatha Reddy; Ashok kumarand Sukhadeo B Barbuddhe (2014): Isolation and Characterization of Listeria Monocytogenes from Goat Brain. Advances in Animal andVet. Sciences. 2 (3S): 12 - 15.

- Simranpreet Kaur; S.V.S. Malik; Kiran N. Bhilegaonkar; Sukhadeo B. Barbuddhe (2010): Use of a phospholipase-C assay, in vivo pathogenicity assays and PCR in assessing the virulence of Listeria spp. The Veterinary Journal Volume 184, Issue 3, June 2010, Pages 366-370 
- S. Kaur, S.V.S. Malik, V.M. Vaidyaand S.B. Barbuddhe (2007): Listeria monocytogenes in spontaneous abortions in humans and its detection by multiplex PCR Journal of Applied Microbiology Volume 103, Issue 5, pages 1889-1896, November 2007.

- Ward T J, Gorski L, Borucki M K, Mandrell R E, Hutchins J, Pupedis K J Bacteriol. (2004): Intraspecific phylogeny and lineage group identification based on the prfA virulence gene cluster of Listeria monocytogenes. Aug; 186(15):4994-5002.

- Zhang, C., M. Zhang, J. Ju, J. Nietfeldt, J. Wise, P. M. Terry, M. Olson, S. D. Kachman, M. Wiedmann, M. Samadpour, and A. K. Benson. (2003): Genome diversification in phylogenetic lineages I and II of Listeria monocytogenes: identification of segments unique to lineage II populations. J. Bacteriol. 1855573-5584.

$$
\begin{aligned}
& \text { كثف الجينات المتعددة المرتبطة بالضراوة فى ميكروب الليستيريا مونوسيتوجين } \\
& \text { المعزولة من حيو انات المزر عة المريضة. }
\end{aligned}
$$

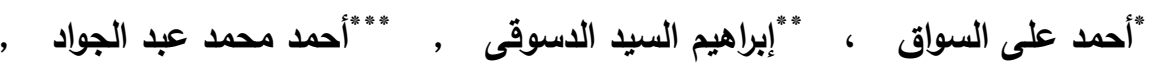

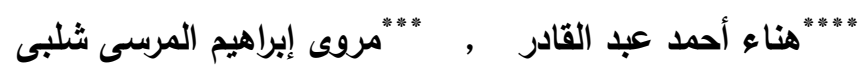

$$
\begin{aligned}
& \text { قسم الباثولوجيإ- كليه الطب البيطرى - جامعه كفر الشيخ, مصر } \\
& \text { "قسم البكتريولوجيا وإلفطريات وإلمناعة كلية الطب البيطري- جامعة كفرالثبخ , مصر } \\
& \text { "*." معه بحوث صحة الحيوان , معه المنصورة الفرعى. }
\end{aligned}
$$


"رئيس وحدة الجينوم, معهل بحوث صحة الحيوان.

من الفحص البكتيري لعدد 631 عينة (لبن, براز , مخ و سائل النخاع الثوكى ) تم تجميعها من ( 80 أغنام , 60 ماعز ,75 أبقار و 53 جاموس) من الحالات المريضـة وحالات الذبح الاضطراري فى الفترة (2014-2015 من أجل عزل ميكروب ليستيريا مونوسيتوجين وكانت النسبة الايجابية فى الأبقار (24.48\%), الجاموس (17.4\%), الأغنام (36.5\%) و الـاعز(28.67\%). بإجراء تفاعل البلمرة المتسلسل و تفاعل البلمرة المتسلسل المركب للعترات المصنفة الليستيريا مونوسيتوجين ظهرت inlJ, inlB, plcB, hylA, jap, inlA and inlC (أحجام القواعد النيتروجينية لجينات الضراوة (actA plcA 